\title{
Reintroduction of fen plant communities on a degraded minerotrophic peatland
}

\begin{tabular}{|r|l|}
\hline Journal: & Botany \\
\hline Manuscript ID & cjb-2016-0023.R2 \\
\hline Manuscript Type: & Article \\
\hline Date Submitted by the Author: & 1 7-Jun-2016 \\
\hline Complete List of Authors: & $\begin{array}{l}\text { Rochefort, Line; University Laval, } \\
\text { LeBlanc, Marie-Claire; University Laval, Phytologie } \\
\text { Bérubé, Vicky; Universit } \\
\text { Hugron, Laval, Phytologie } \\
\text { Boudreau, Stéphanie; Univer Universite Laval } \\
\text { Pouliot, Rémy; Universite Laval }\end{array}$ \\
\hline Keyword: & $\begin{array}{l}\text { peatland restoration, diaspore transfer, rewetting, phosphorus fertilization, } \\
\text { moderate-rich fen }\end{array}$ \\
\hline & \\
\hline
\end{tabular}


Reintroduction of fen plant communities on a degraded minerotrophic peatland

Line Rochefort, Marie-Claire LeBlanc, Vicky Bérubé, Sandrine Hugron, Stéphanie Boudreau and Rémy Pouliot

Peatland Ecology Research Group (PERG) and Northern Study Center (CEN), 2425 rue de l’Agriculture, Université Laval, Québec (Québec) G1V 0A6, Canada (e-mail: gret@fsaa.ulaval.ca)

\section{Corresponding author:}

Line Rochefort 2425 rue de l'Agriculture, Université Laval, Québec (Québec) G1V 0A6, Canada Phone: 1-418-656-2131 ext. 2583

Fax: 1- 418-656-7856

Line.Rochefort@fsaa.ulaval.ca 


\section{Summary}

An approach has been developed to restore bogs after peat extraction. However, when sedgepeat layers are exposed, the minerotrophic remnant peat conditions require restoration towards a fen ecosystem. Three restoration techniques, all including rewetting actions, were tested to assist fen vegetation recovery. None of the restoration techniques was efficient at establishing fen bryophytes. However, for vascular plants, two techniques gave promising results in terms of species composition, although the vascular plant covers remained lower than in reference natural fens. Depending on the site conditions, we suggest applying two restoration techniques to restore peatlands in areas of exposed sedge peat. In areas where sparse covers of fen species may have spontaneously established, rewetting should be carried out to raise water level and create favourable conditions for their expansion. In areas covered with undesirable species or with inadequate topography for rewetting, surface peat should be remodeled and vegetation introduced. Since mechanized diaspore transfer did not result in a satisfactory cover of fen plants, other means of introduction could be considered, alone or in combination. A complementary fertilization experiment showed that $\mathrm{P}$ fertilization could be an effective solution to enhance the establishment of mechanically introduced plant diaspores.

Key words: moderate-rich fen, peatland restoration, diaspore transfer, rewetting, phosphorus fertilization. 


\section{Résumé}

Une approche efficace a été développée pour restaurer les tourbières ombrotrophes (bogs) après l'extraction de tourbe. Toutefois, lorsque la tourbe de Carex est exposée, la restauration vers une tourbière minérotrophe (fen) semble plus appropriée. Trois techniques de restauration (incluant toutes l'étape du remouillage) ont été testées. Aucune des techniques n'a permis l'établissement des bryophytes de fens. Cependant, pour les plantes vasculaires, deux techniques de restauration ont données des résultats encourageants en termes de composition en espèces, même si leurs couverts demeuraient plus faibles que dans les fens naturels. Selon les conditions locales sur le site, nous suggérons d'appliquer ces deux techniques pour restaurer les tourbières où prévalent des conditions de fens. Les zones où des couverts épars d'espèces de fens se sont établis spontanément devraient être remouillées afin d'élever le niveau d'eau et créer des conditions favorables à leur expansion. Les secteurs envahis par des espèces indésirables ou dont la topographie est inadéquate pour le remouillage devraient avoir leur surface remodelée et des plantes devraient être réintroduites. Comme le transfert mécanisé des diaspores n'a pas permis d'obtenir un couvert satisfaisant en espèces de fens, d'autres moyens d'introduction pourraient être envisagés. Une expérience complémentaire de fertilisation a montré que l'ajout de phosphore est un atout pour améliorer l'établissement des bryophytes et des plantes vasculaires introduites mécaniquement par diaspores.

Mots-clés: fen modérément riche, restauration de tourbière, transfert de diaspore, remouillage, fertilisation phosphatée. 


\section{Introduction}

Peat extraction for the production of horticultural substrates results in severe disturbance to natural peatland ecosystems (Graf et al. 2012). To allow machinery circulation and other mechanized activities, water is drained and vegetation is removed from the surface. After years of peat extraction, typical peatland plant communities do not have the capacity to recover in such degraded conditions (Triisberg et al. 2013). As a consequence, peatland surfaces can remain unvegetated decades after the end of industrial activities (Poulin et al. 2005) or be colonized with plant assemblages that are not related to their original composition (Graf et al. 2008). The functions and ecological services normally provided by peatlands are thus not reestablished (Lamers et al. 2015; Wilson et al. 2015). It is in this context that a mechanized restoration technique called the Moss Layer Transfer Technique (MLTT) has been developed (Quinty and Rochefort 2003; Rochefort et al. 2003) and applied successfully to peat-extracted bogs across Canada over the last 20 years (González and Rochefort 2014). The MLTT involves six steps: 1) site preparation: the peatland surface is cleared of vegetation that spontaneously revegetated the site to expose fresh peat, and levelled for better water distribution after rewetting (see step 6). This operation is called "profiling"; 2) diaspore collection: donor material is collected in a natural portion of the peatland; 3) diaspore introduction: donor material is spread on site, following a 1:10 ratio ( $1 \mathrm{~m}^{2}$ of donor material is spread over a $10 \mathrm{~m}^{2}$ surface); 4) diaspore protection: donor material is covered with a protective straw mulch layer; 5) fertilization: light phosphorous fertilizer (usually phosphate rock) is applied to favour the establishment of nursing plants for Sphagnum mosses; and 6) rewetting: main and secondary ditches are blocked (with peat dams or filled with peat during the site preparation step) to raise the water table level. A high water table has been singled out as the major driver leading to 
good vegetation recovery in peat-extracted residual fens (Priede et al. 2016) which supports this restoration action for fens.

Nowadays, peat is most often extracted from bogs down to their underlying sedge peat layers. Indeed, more efficient peat extraction technologies reduce mixes between the bog and fen peat layers, impede "contamination" between the two types of peat, and allow the development of specific substrates or mixes using fen peat (L. Rochefort, personal observation). In other cases, depending on the geomorphological context, groundwater resurgence can be observed when the peat is extracted down to a certain level. The prevailing richer and less acidic conditions are not suitable for the re-establishment of Sphagnum-dominated plant communities and restoration towards a fen ecosystem is more appropriate in these situations (Wind-Mulder et al. 1996; Wind-Mulder and Vitt 2000; Graf and Rochefort 2008a). However, effective large-scale restoration techniques for fens have yet to be tested for this type of environment.

Numerous fen restoration projects have been implemented in Europe (Lamers et al. 2015). Common techniques that have been tested, in combination or alone, include: rewetting, hay transfer, top-soil removal and the return of traditional land-uses like grazing and biomass harvesting (e.g. Pfadenhauer and Grootjans 1999; Patzelt et al. 2001; Rasran et al. 2007; Kiehl et al. 2010; Klimkowska et al. 2010; Hedberg et al. 2012; Lamers et al. 2015). These techniques are mostly aimed at restoring drained fens that have been intensively used for agriculture. In contrast, in North America, the focus of the horticultural peat industry is to restore functional ecosystems with peatland plant communities that can restart the accumulation of organic matter. Also, as opposed to disturbed fens in Europe, the post-extracted peatlands are not completely covered with vegetation (although spontaneous vegetation can occur) and seed banks are inexistent. The sites which are to be restored are harsh environments for plant 
establishment (Campbell et al. 2002; Lavoie et al. 2005) and the European techniques are thus not transferable.

In North America, smaller scale sedge plantations on extracted fens have been successfully completed (Cooper and MacDonald 2000; Rochefort et al. 2015). However, the cost of plantations and the lack of availability of plugs represent major disadvantages. Based on diaspore collection and the reintroduction steps of the MLTT, other small-scale manual trials of reintroducing fen plant communities by soil material transfer have been conducted on minerotrophic residual peat substrates across a diversity of sites. The first attempt at introducing diaspore material from a donor site (the top $10 \mathrm{~cm}$ of surface vegetation) indicated that this is an effective method to increase both vascular fen species cover and richness (Cobbaert et al. 2004). Later, Graf and Rochefort $(2008 a, 2008 b)$ used a similar technique to successfully re-establish true mosses, Sphagnum and Carex species typical of fens. The positive results of earlier studies suggested that donor material transfer should be tested at a larger scale and could be useful in fen restoration projects. Alternatively, the dispersion of diaspores from natural remnant peatlands surrounding industrial minerotrophic sites could contribute to the site's revegetation. This source of propagules has not yet been studied as it was in bogs (Campbell et al. 2003).

As part of the MLTT restoration approach for bogs, phosphorus (P) fertilization is commonly used to accelerate plant establishment (generally under its phosphate rock form, 0-13-0 $\mathrm{P}_{2} \mathrm{O}_{5}$ ) (Ferland and Rochefort 1997; Quinty and Rochefort 2003; Sottocornola et al. 2007). It is used to promote Polytrichum strictum (Ferland and Rochefort 1997), a valuable peat substrate stabilizer when frost heaving is an issue (Groeneveld et al. 2007). Frost heaving appears when the water contained in the peat freezes, which lifts the soil surface and uproots seedlings, creating peat instability (Groeneveld and Rochefort 2002). However, the outcome of P fertilization for whole- 
ecosystem fen restoration in the context of sedge-peat residual substrates is less known. It could have the desirable effect of enhancing above-ground net primary production of graminoids, as $\mathrm{P}$ availability is known to control productivity and community structure in natural fens (Chapin et al. 2004). Such an effect was observed by Graf and Rochefort (2008a) for Carex species. On the other hand, P fertilization could have the undesirable effect of promoting weed invasion as the $\mathrm{pH}$ of sedge peat substrate is higher than that of Sphagnum peat (Lamers et al. 2015). Soil nutrient availability (including P) is believed to be low in peatlands due to a combination of factors including the low pH (Andersen et al. 2011). Addition of lime in a rewetted peatland where peat surfaces were cleared of pre-existing vegetation, increased peat $\mathrm{pH}$ from 4.9 to 6.3 and had a strong positive effect on the survival of introduced fragments of four bryophyte species typical of rich fens (Mälson and Rydin 2007). Thus, the use of P fertilization and liming as tools for restoring post-horticultural peat extracted peatland vegetation has to be further tested in the context of fen restoration.

The overall aim of this project is to assess if any of the restoration steps of the Moss Layer Transfer Technique developed for Sphagnum-dominated peatlands could be an efficient way to re-establish typical fen plant communities, including carpets of true mosses, on the residual minerotrophic peat surface of a former peat extracted bog. Specifically, our experiments focus on comparing the contribution of two sources of propagules (recruitment from adjacent natural sectors or introduction of plant material) for the recovery of fen communities. Additionally, the application of phosphorous fertilizer or lime as adaptive methods to promote the establishment of reintroduced plant material is also examined.

\section{Materials and methods}

Study site 
The study site is located in the Lower-St-Lawrence region $\left(48^{\circ} 19^{\prime} \mathrm{N}, 68^{\circ} 50^{\prime} \mathrm{W}\right.$ ), approximately $285 \mathrm{~km}$ northeast of Québec City, Canada. The climate is relatively cool (average annual temperature $4.4^{\circ} \mathrm{C}$ ) with sub-humid conditions (average annual precipitation $958.5 \mathrm{~mm}$, of which approximately 30\% falls as snow) (Environment Canada 2015). On the northern edge of the site, a low mountain range (345 $\mathrm{m}$ at the highest) extends SW to NE over approximately 10 $\mathrm{km}$. A peatland complex is located at its base, which includes post-extracted peat sectors intermixed with other bogs and fens in their natural state, as well as forest patches and agricultural fields. The Bic-Saint-Fabien (BSF) research station (Fig. 1) is located on a 15-hectare sector of this large peatland complex where peat was extracted for horticultural purposes from 1946 to 2000, and activities ceased thereafter. The thickness of the residual peat layer ranged from a few $\mathrm{cm}$ to $1-2 \mathrm{~m}$.

\section{Site restoration}

In 2009, the industrial peatland where peat had been extracted down to the underlying sedge peat layer was first surveyed to develop a restoration plan. In the interior portion of the site, residual peat had a lower elevation and drainage ditches had collapsed over the years, leading to wetter conditions (Malloy and Price, 2014). These areas were primarily covered with Scirpus cyperinus, Alnus rugosa, Salix spp. and Typha latifolia (L. Rochefort, unpublished data). The drier peripheral areas of the site presented mostly large extents of bare peat. The pore water (averaged over the 15 ha experimental site and measured with a portable $\mathrm{pH}$ and electric conductivity meter (HANNA instruments 98129)) presented moderately rich fen conditions (Vitt et al. 1995): $\mathrm{pH}: 6.1 \pm 0.3$, mean $\pm \mathrm{sd}, \mathrm{n}=80$ and corrected electric conductivity: $334 \pm 158 \mu \mathrm{S}$ $\mathrm{cm}^{-1}$, mean $\pm \mathrm{SD} ; \mathrm{n}=80$ (L. Rochefort, unpublished data). Consequently, the goal of the restoration aimed towards a moderately rich fen ecosystem (cf. fig. 2.2 in Vitt 2006). 
Restoration activities were carried out from winter 2009 to spring 2010, following an adapted version of the Moss Layer Transfer Technique developed for bog restoration (Quinty and Rochefort 2003). Donor material (up to $10 \mathrm{~cm}$ composed of bryophyte fragments and vascular plant seeds, roots and stems) was harvested mechanically in a donor site using an excavator with a hydraulic clamp. The donor site was a moderate-rich riverine fen located between a drained lake and a cedar swamp. Vegetation was dominated by fen bryophytes (mostly Sarmenthypnum exannulatum and Campylium stellatum) and by the sedge Trichophorum alpinum (see Table 1 for a complete list of species present before plants harvesting). At the experimental site, rewetting was carried out at site-scale by blocking the former drainage system with decomposed peat (Malloy and Price 2014). Rewetting the site led to a significant rise of the water table and to a decrease in its intra-seasonal variability, reaching levels that were similar to the ones observed in the adjacent natural fens. Because of climatic conditions at the time of the implementation of the restoration plan and machinery constraints due to limited ground bearing capacity, the centre and western edge of the site were left untouched. In other areas, the top $30 \mathrm{~cm}$ of the peat surface was removed to level the dome-shape of the formerly extracted peat fields, to expose fresh peat and to remove biological crust and spontaneously established vegetation. Over two kilometres of peat berms were built in the areas of the site with higher slopes to ensure an even distribution of the water, leading to the construction of several terraces of various elevations across the site (Fig. 1). No fertilization was applied to prevent weed invasions. The restoration work resulted in the implementation of four different restoration techniques: 1) Mechanical technique: The peatland surface was profiled, donor material was introduced in a 1:10 ratio and protected by straw mulch, both spread mechanically; 2) Profiling technique: The surface was profiled but no plants were introduced; 3) Rewetting technique: The ditches were blocked, with no modification to the surface in order to 
preserve the spontaneously established typical fen vegetation in place; 4) Manual technique: The donor material (collected mechanically) and protective straw were spread by hand over a profiled surface in association with an educative community project.

Adjacent to the experimental site, two natural fens with distinct plant communities are present. On the eastern edge is an Open Wooded Moderate-Rich Fen (OWMRF; 6 ha) dominated by Trichophorum cespitosum, Thuja occidentalis and Myrica gale. The bryophyte cover is mainly composed of Sphagnum rubellum. North of the restored peatland, a Wooded Moderate-rich fen (WMRF) composed of Thuja occidentalis, Larix laricina, Menyanthes trifoliata and Sphagnum warnstorfii extends over 10 ha. Nomenclature of the natural fens follows Locky et al. (2005). A list of species is presented at Table 1.

\section{Establishment of fen plant communities}

Five growing seasons after the restoration, vegetation surveys were performed in all restored sectors. The number of sampling units $(5 \mathrm{~m} \times 5 \mathrm{~m})$ installed in each sector was proportional to its size: five sampling units in the Mechanical and Profiling technique sector and six in the Rewetting technique sectors for a total of 18 sampling units (Fig. 1). The two natural fen portions at the margin of the restored site were also surveyed as a potential propagule sources. Within each sampling units, all vascular plants were identified to species level in four systematically located $1 \mathrm{~m} \times 1 \mathrm{~m}$ quadrats. The surface covered by each species (on the ground, by vertical projection) was estimated, as well as the total surface covered by all vascular plants. Bryophyte cover was estimated following the same method, in 8 or 12 quadrats $(25 \mathrm{~cm} \times 25 \mathrm{~cm})$ also systematically distributed within each sampling units. This survey method is commonly used for long-term vegetation monitoring (for examples and details about the method see D'Astous et al. 2013; Rochefort et al. 2013; González and Rochefort 2014). The number of quadrats needed to 
accurately survey restored peatlands vegetation was tested statistically in 2012 (L. Rochefort, unpublished data). The results of this study showed that 12 quadrats was adequate to evaluate bryophyte abundance and that adding more subsamples did not decrease significantly the variance of the mean.

The vegetation composition of the donor site prior to plant harvesting was evaluated in 2008 . Plant cover was estimated in 16 quadrats systematically distributed along a $375 \mathrm{~m}$ long transect. Vascular plant cover was evaluated in a $1 \mathrm{~m} \times 1 \mathrm{~m}$ quadrat while bryophyte cover was estimated in a $25 \mathrm{~cm} \times 25 \mathrm{~cm}$ quadrat located in a representative location inside the $1 \mathrm{~m}^{2}$ quadrat. Table 1 summarizes sampling effort in each sector.

\section{Fertilizing and liming as vegetation establishment enhancing method}

Two years post-restoration, recovery rate of the reintroduced fen plant material was low. In order to evaluate the possibility of enhancing fen plant establishment after restoration, the effects of lime and phosphate fertilizer were tested. Nine blocks were delineated within homogeneously revegetated areas of the Mechanical and Manual technique sectors. In each block, three treatments were applied in July 2012: 1) Liming: $15 \mathrm{~g} \mathrm{~m}^{-2}$ of dolomitic lime $\left(\mathrm{CaCO}_{3}\right.$ : 69\%; $\left.\left.\mathrm{MgCO}_{3}: 22 \%\right) ; 2\right) \mathrm{P}$ fertilization: $25 \mathrm{~g} \mathrm{~m}^{-2}$ of granular phosphate rock $\left(0-13-0 ; \mathrm{P}_{2} \mathrm{O}_{5}\right.$ total $25 \%, \mathrm{P}_{2} \mathrm{O}_{5}$ available $\left.13 \%\right)$; 3) Control: no modification. Each treatment was applied by hand over a $2 \mathrm{~m} \times 10 \mathrm{~m}$ sampling unit, leaving a one metre-wide buffer zone in between the sampling units to prevent cross-contamination. Two years after the treatments were implemented (four years after the restoration), plant abundance was surveyed. Within each sampling unit, vascular plant cover was estimated (for each species and the total coverage) in three systematically located 1 $\mathrm{m} \times 1 \mathrm{~m}$ quadrats. Bryophyte cover was estimated in three $50 \mathrm{~cm} \times 50 \mathrm{~cm}$ quadrats, each located 
systematically within a vascular plant quadrat. Peat samples were collected for each sampling unit, and $\mathrm{pH}$ was measured by water dilution 1:1.

\section{Statistical analyses}

Since restoration techniques were applied at a large scale on one experimental site, and to avoid pseudoreplication issues (Hurlbert 1984), Principal Component Analysis (PCA; scaling one) was performed to compare plant assemblages between the restored sampling units and the natural fens considered as potential propagule source. Data computed in the analysis was the mean species abundance five years after restoration in one given sampling unit $\left(25 \mathrm{~m}^{2}\right)$ for all BSF sectors ( 3 restored sectors and 2 natural portions of the surrounding fen). The manual technique was removed from this analysis for many reasons: higher soil instability; a different timing of plant reintroduction, which could generate bias; smaller sector and further from natural fens than other restored sectors; closer to the parking area and adjacent agricultural fields which can be important sources of ruderal species propagules. For the donor site, data computed in the analysis was the species abundance in 16 sampling units $\left(1 \mathrm{~m}^{2}\right)$ prior to vegetation harvesting (2008). To minimize bias induced by rare species (present in less than three sampling units with mean cover, when it was present, of less than $3 \%)$, these were not included in the analysis. Since our data set included many plots with low plant abundances (especially in the restored sectors), abundance data were transformed using the Hellinger transformation method prior to analysis, thus solving the double zero problem (Legendre and Gallagher 2001). R software ( $R$ Development Core Team 2014) was used with the Vegan package (Oksanen et al. 2014) to perform this analysis. To assess the effect of fertilization treatments, paired t-tests were performed to compare the peat $\mathrm{pH}$ of each sampling unit before and two years after fertilizing treatments with SAS (SAS Statistical System software ver. 9.3, SAS Institute inc., Cary, U.S.A.). To 
assess the effects of fertilization on vegetation cover, mean cover by strata (total vegetation, vascular plants and bryophytes) was analyzed with ANOVA for a completely randomized block design using the GLM procedure of SAS. Protected Fisher's LSD test was used for comparison of mean $(\alpha=0.05)$. Normality and homogeneity assumptions were verified.

\section{Results}

Establishment of fen plant communities

After five post-restoration growing seasons, all sectors exhibited a total vegetation cover that was lower and more heterogeneous than what was found in the two adjacent natural fens and the donor site (Table 1). The difference is particularly important for the bryophytes that are a major component of natural fens, which were virtually absent from all restored sectors. Fen bryophytes did not establish from diaspores in sectors where donor material was introduced, as shown by their cover that was similar to the sector that was only profiled with no plant reintroduction (Table 1).

The Rewetting sector exhibited a high vascular plant cover (Table 1), reaching abundances similar to those observed in the surrounding natural fens. However, in both the Profiling and the Mechanical technique sectors, vascular plant cover was low and patchy. In terms of species composition, the Mechanical technique sector was dominated by species that were also abundant in the donor site (Myrica gale, Trichophorum alpinum and Sanguisorba canadensis) (Fig. 2; Table 1). On the opposite, the species assemblage present in the two sectors where no vegetation was introduced (Rewetting and Profiling technique sectors), was different from the one observed in three ecosystems considered as potential sources of propagules (Fig. 2; Table 
1). For example, species like Scirpus cyperinus, Spiraea alba var. latifolia and Calamagrostis canadensis were dominant in the Rewetting and Profiling technique sectors whereas Trichophorum species, different trees (e.g. Thuja occidentalis) and a great diversity of forbs dominated the surrounding natural fens. The only fen species that seemed to be able to establish from the surrounding natural fens was Myrica gale, as exhibited by its relatively high covers in the Rewetting technique sector. Carex aquatilis was found in abundance in some of the sampling units of the Profiling technique sector where it spread by vegetative propagation from former drainage ditches. The origin of the establishment of the species in the drainage ditches of the sites is, however, unknown.

Fertilizing and liming as vegetation establishment enhancing methods Vegetation cover was 1.8 times higher in sampling units fertilized with phosphorous, compared to limed or control sampling units $\left(F_{2,16}=13.8 ; p=0.0003 ;\right.$ Fig. 3$)$. This increase in cover was observed both for vascular plants $\left(F_{2,16}=10.6 ; p=0.001\right)$ and bryophytes $\left(F_{2,16}=11.25 ; p=\right.$ 0.0009). Two years after fertilization, the $\mathrm{pH}$ of peat in limed treatment increased from $4.4 \pm 0.2$ to $5.4 \pm 0.4$ (mean $\pm \mathrm{SD} ; \mathrm{t}=7.7, \mathrm{df}=8, \mathrm{p}<0.0001$ ). A smaller, but still significant increase in $\mathrm{pH}$ was also observed for the other treatment (control: $+0.5 ; t=4.5, d f=8, p=0.002$ and $P$ fertilization: $+0.6 ; t=4.1, d f=8, p=0.003)$.

\section{Discussion}

Large scale manipulations aiming at restoring fen plant communities

Bryophytes form a major component (in terms of diversity and cover) of natural fen vegetation (Rydin and Jeglum 2013). Similarly to the rapid establishment of Sphagnum rubellum in restored 
bogs that indicates success (González et al. 2013), rapid fen bryophyte establishment would likely be an indicator of fen restoration success. The restoration trials conducted during this project showed that establishment of fen bryophytes over large scales is more challenging than anticipated. Poor bryophyte recruitment in the Rewetting and Profiling technique sectors indicated that relying on spontaneous colonization (mainly via spore germination) is not a suitable option for the revegetation of sedge-peat substrate. Introduction of bryophyte fragments (mainly gametophytes along with some sporophytes) did not enhance fen bryophyte establishment either. This result is somewhat surprising since previous small-scale experiments had shown that bryophytes establishment is possible when diaspore reintroduction is carefully carried out by hand (Mälson and Rydin 2007; Graf and Rochefort 2008b). In the same way, other small-scale trials carried out manually on the same experimental research site with material from the same donor site resulted in dense true moss and Sphagnum covers (L. Rochefort, unpublished data). These experiments were, however, located in wetter conditions than what was prevailing in the Mechanical technique sector. Moreover, when plant collection for reintroduction is performed manually, only a thin layer of bryophytes is harvested whereas mechanical harvesting results in the collection of peat along with the desired donor material. The bryophytes thus get mixed with peat in the harvesting and spreading processes, which could have limited their ability to regenerate once introduced on the surface of the restoration area. Also, true moss fen diaspores could also be less resistant to the stresses induced by the collection and spreading operations (storage in piles, heat, lack of water) than bog material. In a different study in Northern Alberta, very low fen bryophyte establishment was also observed following mechanical restoration in a restoration project on decommissioned well pads (Gauthier 2014), supporting the need to investigate the effects of mechanical manipulation on the regeneration of fen mosses. 
When considering vascular plant establishment, among all restoration techniques tested, the Rewetting technique led to the highest covers. This result is mainly explained by the fact that vegetation established prior to restoration (a time span of 8 years between the end of peat extraction and restoration) was preserved. The relatively wet conditions prevailing after peat extraction are likely what allowed the dominant colonization of fen species (mainly Scirpus cyperinus). Five years after the restoration, these species were still dominant. The successful rewetting (Malloy and Price 2014) also created suitable conditions for the expansion of other fen species that were already sparsely present before the restoration, like Calamagrostis canadensis, Myrica gale, Spiraea alba var. latifolia and Trichophorum alpinum. The Rewetting technique might therefore be considered for specific situations where fen-type vegetation is already present and the objective is to improve hydrology in order to enhance plant fen community development. However, many different outcomes are possible after rewetting and point to the need for monitoring when this method is used on its own (Klimkowska et al. 2010; Hedberg et al. 2012; Klimkowska et al. 2015; Lamers et al. 2015).

Conversely, the Profiling technique resulted in low vascular plant establishment with species atypical of fens occupying almost half of the space. In this sector, plant recruitment relied solely on seed dispersion from surrounding ecosystems. We expected that the rise in the water table following rewetting would have resulted in plant establishment rates similar to what was observed in the Rewetting technique sector prior to restoration. However, a very low plant establishment rate from the dispersion of diaspores from the surrounding natural fens was observed and the only species that exhibited important covers (Carex aquatilis) spread vegetatively from pre-existing colonies in the former drainage ditches. The Profiling technique 
should therefore not be considered for the re-establishment of fen plant communities on industrial peatlands extracted down to sedge peat layers.

The introduction of donor material in the Mechanical technique sector led to the establishment of a community dominated by the plant species that were abundant in the donor site, with the exception of the Carex species (see Table 1) and Schoenoplectus tabernaemontani. Establishment of Carex species is often problematic in fen restoration projects (van der Valk et al. 1999; Cooper and MacDonald 2000; Patzelt et al. 2001), in part because of their low germination rates (Patzelt et al. 2001). The transfer of donor material solved this issue by introducing rhizomes along with other plant diaspores and was shown to be effective in establishing some, but not all introduced, Carex species (Cobbaert et al. 2004; Graf and Rochefort 2008a). Unfortunately, even if this technique was successful at transferring some fen species, it resulted in a low plant covers that can compared to the recovery rate observed in the Profiling technique sector. The low vascular establishment can be explained, in part, by various factors. For example, the successful rewetting increased the prevalence of frost heaving and erosion by water flow, especially in the sectors where large extents of bare peat had been exposed by profiling operations. Peat instability is known to be harmful for plant establishment (Quinty and Rochefort 2000; Campbell et al. 2002) by displacing introduced vegetation (erosion) or uprooting seedlings (frost heaving). In addition, the choice of the donor site was originally oriented towards a high bryophyte density rather than vascular plant density and the timing of plant harvesting (late fall) was also not optimal to collect ripe seeds from the vascular plants. Because of the logistics and costs involved with this method, we do not deem it worthwhile to pursue it at a large-scale for this type of moderate-rich fen, unless significant improvements are made to enhance plant establishment. 


\section{Amendments as an adaptive restoration tool}

Results from the second experiment suggest that the application of phosphorus is a good adaptive management practice to enhance both vascular plant and bryophyte establishment. Depending on the initial vegetation that was present in the field, increase in cover was observed for several species (like Bryum pseudotriquetrum, Trichophorum alpinum and Scirpus cyperinus). In this study, phosphate rock was not considered initially in the restoration plan of the Mechanical technique sector in order to prevent the proliferation of unwanted species and avoid the expansion of ruderal species from nearby agricultural fields because of the higher $\mathrm{pH}$ of the residual sedge-peat substrate. However, it appears that $\mathrm{P}$ application is a good adaptive restoration tool which improves the establishment of introduced fen species without favouring the establishment of unwanted species. The amount of phosphate rock tested within this project followed the recommendation of the MLTT (Sottocornola et al. 2007), but further trials should seek specific ideal dosage and timing of application for fen vegetation. Liming application increased the peat $\mathrm{pH}$ but did not translate to an improved vegetation cover, unlike the results from Mälson and Rydin (2007) who observed a strong positive effect of liming on the survival of fen true moss fragments. This suggests that liming should be applied before bryophyte introduction rather than as a corrective measure a few years after plant introduction.

\section{Conclusion}

The restoration of the Bic-St-Fabien peatland is the first ecosystem-scale fen restoration project following industrial peat extraction in North America. Over five growing seasons, none of the three restoration techniques tested succeeded in satisfactorily establishing typical fen plants. 
Bryophytes appeared especially recalcitrant to regenerate into carpets and covers comparable to what is found in natural fens, whether the propagules were introduced from a donor site or recruited from an adjacent natural peatland. Vascular plant establishment was not as high as expected, but resulted in extensive cover in the Rewetting technique. With the Mechanical technique restoration approach, vascular plant assemblages showed more similarity to the donor site composition. When only remodeling the peat substrate, clearing the biological crust and rewetting the site without plant reintroduction, the Profiling technique clearly demonstrated that spontaneous revegetation from natural dispersion of diaspores does not lead to typical fen species and that for the vascular strata, reintroduction of donor material is essential to launch the establishment of the desired species.

After five years post-restoration and monitoring, we conclude that the restoration techniques tested in this study are not directly transferable to fen restoration and have to be adapted. The results obtained highlight the importance of finding restoration methods that can accelerate and improve the establishment of fen species. Alternatively, restoration projects could include a combination of techniques on a same degraded peatland presenting heterogeneous local conditions or aiming at more than one restoration objective. In peatland sectors where spontaneously established vegetation is frequent and dominated by non-invasive species, rewetting could be sufficient to create suitable conditions for fen plant establishment or expansion. In the sectors where spontaneous vegetation is dominated by undesirable species or where no vegetation is present or where major surface operations like ditch backfilling, berm construction and reprofiling are recommended. These restoration actions could be associated with the mechanical plant reintroduction to facilitate the return of vascular plants. However, further research is needed to evaluate the effect of fen vascular plant on limiting frost heaving 
and creating favourable microclimatic conditions to facilitate bryophyte establishment before investing in a costly plant reintroduction program. Other alternatives could also be considered to accelerate plant establishment, by individual plantations or in combination with the mechanical introduction of diaspores. Plantations, transplantation or seeding of vascular plants could be considered locally and would also have the beneficial side-effects of rapidly stabilizing the peat surface and contribute to reducing the negative impacts of frost heaving and erosion. As fen plants are responsive to phosphorus applications, $\mathrm{P}$ fertilization is an additional restoration tool to favour rapid plant establishment. The promising results obtained when fertilizing fen plants should be further explored.

Nevertheless, when the final aim is to restore fen peat mosses, more research is required to properly understand the environmental filters impeding the establishment and recovery of the fen true moss carpet. The effect of mechanical harvesting on the donor material and the ideal timing for collecting and spreading the diaspores are among the topics that should be further investigated to develop a truly efficient restoration technique for fens.

\section{Acknowledgements}

Financial support was provided by the Ministère des Transports du Québec, the Natural Sciences and Engineering Research Council of Canada, the Canadian Sphagnum Peat Moss Association and its members. We thank the numerous field assistants that helped for the site restoration and for the data survey at the Bic-Saint-Fabien site, as well as all members of the Peatland Ecology Research Group. Special thanks go to landowners that granted us access to their lands. We are grateful to C. Boismenu and F. Amyot for format and English revision as well as an 
anonymous reviewer and N. Fenton who provided constructive comments on earlier versions of the manuscript. 


\section{References}

Andersen, R., Rochefort, L., and Landry, J. 2011. La chimie des tourbières du Québec : une synthèse de 30 années de données. Nat. Can. 135(1): 5-14.

Brouillet, L., Coursol, F., Meades, S.J., Favreau, M., Anions, M., Bélisle P., and Desmet, P. 2010+. VASCAN, The database of vascular plants of Canada [on line]. Available at: http://data.canadensys.net/vascan/_(accessed 28 April 2016).

Campbell, D.R., Lavoie, C., and Rochefort, L. 2002. Wind erosion and surface stability in abandoned milled peatlands. Can. J. Soil Sci. 82(1): 85-95. doi:10.4141/S00-089.

Campbell, D.R., Rochefort, L., and Lavoie, C. 2003. Determining the immigration potential of plants colonizing disturbed environments: the case of milled peatlands in Québec. J. Appl. Ecol. 40: 78-91. doi: 10.1046/j.1365-2664.2003.00782.x

Chapin, C.T., Bridgham, S.D., and Pastor, J. 2004. pH and nutrient effects on above-ground net primary production in a Minnesota, USA bog and fen. Wetlands 24(1): 186-201. doi:10.1672/0277-5212(2004)024[0186:PANEOA]2.0.CO;2.

Cobbaert, D., Rochefort, L., and Price, J.S. 2004. Experimental restoration of a fen plant community after peat mining. Appl. Veg. Sci. 7: 209-220. doi:10.1111/j.1654109x.2004.tb00612.x.

Cooper, J.D., and MacDonald, L.H. 2000. Restoring the vegetation of mined peatlands in the southern Rocky Mountains of Colorado, U.S.A. Restor. Ecol. 8(2): 103-111. doi:10.1046/j.1526100x.2000.80016.x.

D'Astous, A., Poulin, M., Aubin, I., and Rochefort, L. 2013. Using functional diversity as an indicator of restoration success of a cut-over bog. Ecol. Eng. 61: 519-526. doi:10.1016/j.ecoleng.2012.09.002. 
Environment Canada. 2015. Canadian climate normals 1971-2010 [online]. Available from http://climate.weather.gc.ca/climate_normals/index_e.html [accessed 19 November 2015].

Faubert, J. 2013. Flore des bryophytes du Québec-Labrador. Volume 2 : Mousses, première partie. Société québécoise de bryologie, Saint-Valérien, QC.

Faubert, J. 2014. Flore des bryophytes du Québec-Labrador. Volume 2 : Mousses, seconde partie. Société québécoise de bryologie, Saint-Valérien, QC.

Ferland, C., and Rochefort, L. 1997. Restoration techniques for ombrotrophic peatlands. Can. J. Bot. 75: 1110-1118.

Gauthier, M.-E. 2014. Restoring peatland plant communities on mineral well pads. M.Sc. thesis, Université Laval, Québec, QC.

González, E., and Rochefort, L. 2014. Drivers of success in 53 cutover bogs restored by a moss layer transfer technique. Ecol. Eng. 68: 279-290. doi:10.1016/j.ecoleng.2014.03.051.

González, E., Rochefort, L., Boudreau, S., Hugron, S., and Poulin, M. 2013. Can indicator species predict restoration outcomes early in the monitoring process? A case study with peatlands. Ecol. Indic. 32: 232-238. http://dx.doi.org/10.1016/j.ecolind.2013.03.019.

Gouvernement du Québec, Ministère de l'Énergie et des Ressources naturelles (2001) Orthophoto of the Province of Québec 1/40 000 01211-085. Black and white, TIFF format, 61 Mo, Géoboutique Québec, Québec.

Graf, M.D., and Rochefort, L. 2008a. Techniques for restoring fen vegetation on cut-away peatlands in North America. Appl. Veg. Sci. 11: 521-528. doi:10.3170/2008-7-18565.

Graf, M.D., and Rochefort, L. 2008b. Moss regeneration for fen restoration: field and greenhouse experiments. Restor. Ecol. 18(1): 121-130. doi: 10.1111/j.1526-100X.2008.00437.x. Graf, M.D., Rochefort, L., and Poulin, M. 2008. Spontaneous revegetation of cutaway peatlands of North America. Wetlands 28(1): 28-39. doi:10.1672/06-136.1. 
Graf, M.D., Bérubé, V., and Rochefort, L. 2012. Restoration of peatlands after peat extraction: Impacts, restoration goals, and techniques. In Restoration and Reclamation of Boreal Ecosystems. Edited by D.H. Vitt and J.S. Bhatti. Cambridge University Press, Cambridge, U.K. pp. 259-280.

Groeneveld, E.V.G., and Rochefort, L. 2002. Nursing plants in peatland restoration: on their potential use to alleviate frost heaving problems. Suo 53 (3-4): 73-85.

Groeneveld, E.V.G., Massé, A., and Rochefort, L. 2007. Polytrichum strictum as a nurse-plant in peatland restoration. Restor. Ecol. 15(4): 709-719. doi: 10.1111/j.1526-100X.2007.00283.x.

Hedberg, P., Kotowski, W., Saetre, P., Mälson, K., Rydin, H., and Sundberg, S. 2012. Vegetation recovery after multiple-site experimental fen restorations. Biol. Conserv. 147(1): 60-67. doi:10.1016/j.biocon.2012.01.039.

Hurlbert, S.H. 1984. Pseudoreplication and the design of ecological field experiments. Ecol. Monogr. 54(2): 187-211. doi:10.2307/1942661.

Kiehl, K., Kirmer, A., Donath, T.W., Rasran, L., and Hölzel, N. 2010. Species introduction in restoration projects - evaluation of different techniques for the establishment of semi-natural grasslands in Central and Northwestern Europe. Basic Appl. Ecol. 11: 285-299. doi:10.1016/j.baae.2009.12.004.

Klimkowska, A., Kotowski, W., Van Diggelen, R., Grootjans, A.P., Dzierża, P., and Brzezińska, K. 2010. Vegetation re-development after fen meadow restoration by topsoil removal and hay transfer. Restor. Ecol. 18(6): 924-933. doi:10.1111/j.1526-100X.2009.00554.x.

Klimkowska, A., Elst, D.J., and Grootjans, A.P. 2015. Understanding long-term effects of topsoil removal in peatlands: overcoming thresholds for fen meadows restoration. App. Veg. Sci. 18(1): 110-120. doi:10.1111/avsc.12127. 
Lamers, L.P.M., Vile, M.A., Grootjans, A.P., Acreman, M.C., van Diggelen, R., Evans, M.G., Richardson, C.J., Rochefort, L., Kooijman, A.M., Roelofs, J.G.M., and Smolders, A.J.P. 2015. Ecological restoration of rich fens in Europe and North America: from trial and error to an evidence-based approach. Biol. Rev. 90: 182-203. doi:10.1111/brv.12102.

Lavoie, C., Marcoux, K., Groeneveld, E., and Price, J.S. 2005. The dynamics of a cotton-grass (Eriophorum vaginatum L.) cover expansion in a vacuum-mined peatland, southern Québec, Canada. Wetlands 25(1): 64-75. doi:10.1672/0277-5212(2005)025[0064:TDOACE]2.0.CO;2.

Legendre, P., and Gallagher, E.D. 2001. Ecologically meaningful transformations for ordination of species data. Oecologia 129: 271-280. doi:10.1007/s004420100716

Locky, D.A., Bailey, S.E., and Vitt, D.H. 2005. The vegetational ecology of black spruce swamps, fens, and bogs in southern boreal Manitoba, Canada. Wetlands 25(3): 564-582.

Malloy, S., and Price, J.S. 2014. Fen restoration on a bog harvested down to sedge peat: A hydrological assessment. Ecol. Eng. 64: 151-160. doi:10.1016/j.ecoleng.2013.12.015.

Mälson, K., and Rydin, H. 2007. The regeneration capabilities of bryophytes for rich fen restoration. Biol. Conser. 135(3): 435-442. doi:10.1016/j.biocon.2006.10.017.

Oksanen, J.F., Blanchet, G., Kindt, R., Legendre, P., Minchin, P.R., O'Hara, R.B., Simpson, G.L., Solymos, P.M., Stevens, H.H., and Wagner, H. 2014. Vegan: Community Ecology Package. R package version 2.2-0 [online]. Available from http://CRAN.R-project.org/package=vegan.

Patzelt, A., Wild, U., and Pfadenhauer, J. 2001. Restoration of wet fen meadows by topsoil removal: vegetation development and germination biology of fen species. Restor. Ecol. 9(2): 127-136. doi: 10.1046/j.1526-100x.2001.009002127.x.

Pfadenhauer, J., and Grootjans, A.P. 1999. Wetland restoration in Central Europe: aims and methods. Appl. Veg. Sci. 2(1): 95-106. doi:10.2307/1478886. 
Poulin, M., Rochefort, L., Quinty, F., and Lavoie, C. 2005. Spontaneous revegetation of mined peatlands in eastern Canada. Can. J. Bot. 83: 539-557. doi: 10.1139/B05-025.

Poulin, M., Andersen, R., and Rochefort, L. 2012. A new approach for tracking vegetation change after restoration: A case study with peatlands. Restor. Ecol. 21(3): 363-371. doi:10.1111/j.1526100X.2012.00889.x.

Priede, A., Mežaka, A., Dobkeviča, L., and Grīnberga, L. 2016. Spontaneous revegetation of cutaway fens: can it result in valuable habitats? Mires and Peat 18: Art. 06. [online: www.miresand-peat.net/pages/volumes/map18/map1806.php]. doi:10.19189/MaP.2016.OMB.220

Quinty, F., and L. Rochefort. 2000. Bare peat substrate instability in peat land restoration: problems and solutions. In Sustaining our peatlands. Proceedings of the 11th International Peat Congress, Volume II, Quebec City, QC, 6-12 August 2000. Edited by L. Rochefort and J.-Y. Daigle. Canadian Society of Peat and Peatlands \& International Peat Society, Edmonton, AB. pp. 751756.

Quinty, F., and Rochefort, L. 2003. Peatland restoration guide, $2^{\text {nd }}$ ed. Canadian Sphagnum Peat Moss Association and New Brunswick Department of Natural Resources and Energy, Quebec, QC.

R Development Core Team. 2014. R: A language and environment for statistical computing. $R$ Foundation for Statistical Computing, Vienna, Austria [online]. Available from http://www.Rproject.org/.

Rasran L., Vogt K., and Jensen, K. 2007. Effects of topsoil removal, seed transfer with plant material and moderate grazing on restoration of riparian fen grasslands. Appl. Veg. Sci. 10(3): 451-460. doi:10.1111/j.1654-109X.2007.tb00444.x. 
Rochefort, L., Quinty, F., Campeau, S., Johnson, K.W., and Malterer, T.J. 2003. North American approach to the restoration of Sphagnum dominated peatlands. Wetl. Ecol. Manage. 11(1-2): 320. doi:10.1023/A:1022011027946.

Rochefort, L., Isselin-Nondedeu, F., Boudreau, S., and Poulin, M. 2013. Comparing survey methods for monitoring vegetation change through time in a restored peatland. Wet. Ecol. Manage. 21: 71-85, doi:10.1007/s11273-012-9280-4.

Rochefort, L., LeBlanc, M.-C., Pouliot, R., Hogue-Hugron, S., D’Amour, N., Boismenu, C. 2015. Restauration écologique des tourbières de Bic-Saint-Fabien et de Saint-Fabien-sur-Mer dans le Bas-Saint-Laurent. Projet R719.1, Final report presented to Ministère des Transports du Québec. Groupe de recherche en écologie des tourbières, Université Laval, Québec, QC.

Rydin, H., and Jeglum., J.K. 2013. The biology of peatlands, second edition. Oxford University Press, New York, N.Y.

Sjörs, H. 1952 On the relation between vegetation and electrolytes in north Swedish mire waters. Oikos 2: 241-258. Sottocornola, M., Boudreau, S., and Rochefort, L. 2007. Peat bog restoration: Effects of phosphorus on plant re-establishment. Ecol. Eng. 31: 29-40. doi:10.1016/j.ecoleng.2007.05.001.

Triisberg, T., Karofeld, E., and Paal, J. 2013 Factors affecting the re-vegetation of abandoned extracted peatlands in Estonia: a synthesis from field and greenhouse studies. Est. J. Ecol. 62(3): 192-211. doi: 10.3176/eco.2013.3.02

van der Valk, A.G., Bremholm, T.L., and Gordon, E. 1999. The restoration of sedge meadows: seed viability, seed germination requirements, and seedling growth of Carex species. Wetlands 19: 756-764, doi:10.1007/BF03161782. 
Vitt, D.H. 2006. Functional characteristics and indicators of boreal peatlands. In Boreal peatland ecosystems. Edited by R.K. Wieder and D.H. Vitt. Ecological Studies. Springer-Verlag, Berlin, Germany. pp. 9-24.

Vitt, D.H., Bayley, S.E., and Jin, T.L. 1995. Seasonal variation in water chemistry over a bog-rich fen gradient in Continental Western Canada. Can. J. Fish. Aquat. Sci. 52(3): 587-606. doi: 10.1139/f95-059.

Wilson D., Dixon, S.D., Artz, R.R.E., Smith, T.E.L., Evans, C.D., Owen, H.J.F., Archer, E., and RenouWilson, F. 2015. Derivation of greenhouse gas emission factors for peatlands managed for extraction in the Republic of Ireland and the United Kingdom. Biogeosciences 12: 5291-5308. doi:10.5194/bg-12-5291-2015.

Wind-Mulder, H.L., and Vitt, D.H. 2000. Comparison of water and peat chemistries of a postharvested and undisturbed peatland with relevance to restoration. Wetlands 20: 616-628. doi: 10.1672/0277-5212(2000)020[0616:COWAPC]2.0.CO;2.

Wind-Mulder, H.L., Rochefort, L., and Vitt, D.H. 1996. Water and peat chemistry comparisons of natural and post-harvested peatlands across Canada and their relevance to peatland restoration. Ecol. Eng. 7(3): 161-181. doi:10.1016/0925-8574(96)00004-3. 
Table 1: Cover (mean (SE)) of dominant species in the three restored sectors of Bic-Saint-Fabien (BSF) and the three natural sectors that were considered as potential sources of propagules (two surrounding natural sectors of BSF that are adjacent to the restored peatland and the donor site).

\begin{tabular}{|c|c|c|c|c|c|c|c|}
\hline & \multirow{2}{*}{\multicolumn{3}{|c|}{ Restoration technique }} & \multirow{2}{*}{\multicolumn{3}{|c|}{ Propagule source }} \\
\hline & & & & & & & \\
\hline & & Mechanical & Rewetting & Profiling & OWMRF* & WMRF† & Donor site \\
\hline \multicolumn{2}{|c|}{ Sampling units $\left(25 \mathrm{~m}^{2}\right) /$ sector } & 5 & 6 & 5 & 3 & 3 & 15 \\
\hline \multicolumn{2}{|c|}{ Vascular plants sub-samples $\left(1 \mathrm{~m}^{2}\right)$ / sampling unit } & 4 & 4 & 4 & 4 & 4 & 1 \\
\hline \multicolumn{2}{|c|}{ Bryophytes sub-samples $\left(625 \mathrm{~cm}^{2}\right) /$ sampling unit } & 8 & 8 & 8 & 12 & 12 & 1 \\
\hline \multirow[t]{4}{*}{ Code PCA } & Vascular plants $\S$ & $26(8)$ & $65(12)$ & $24(13)$ & $84(9)$ & $86(8)$ & $59(7)$ \\
\hline & Abies balsamea & & & & & $1(1)$ & \\
\hline & Carex aquatilis & & $<1$ & $10(13)$ & & & $4(3)$ \\
\hline & Carex disperma & & & & & $4(3)$ & \\
\hline Car fla & Carex flava & $<1$ & & & & & $5(4)$ \\
\hline \multirow[t]{2}{*}{ Car las } & Carex lasiocarpa & & & & $<1$ & & $7(4)$ \\
\hline & Chamaedaphne calyculata & $1(1)$ & & & & & $1(0.3)$ \\
\hline \multirow[t]{4}{*}{ Doe umb } & Doellingeria umbellata & $1(1)$ & $<1$ & $<1$ & $<1$ & $<1$ & $1(0.3)$ \\
\hline & Eriophorum angustifolium & $<1$ & & $<1$ & & $<1$ & $1(0.5)$ \\
\hline & Gaultheria hispidula & & & & & $1(1)$ & \\
\hline & Kalmia angustifolia & & & $<1$ & $2(3)$ & $1(2)$ & $<1$ \\
\hline \multirow[t]{3}{*}{ Lar lar } & Larix laricina & $<1$ & $1(1)$ & $<1$ & $2(1)$ & $20(8)$ & $<1$ \\
\hline & Linnaea borealis & & & & $1(2)$ & $<1$ & \\
\hline & Maianthemum trifolium & & & & & $1(1)$ & \\
\hline Men tri & Menyanthes trifoliata & & & & $2(2)$ & $10(9)$ & \\
\hline Myr gal & Myrica gale & $6(3)$ & $8(5)$ & $<1$ & $19(7)$ & $4(2)$ & $9(2)$ \\
\hline \multirow[t]{3}{*}{ Par gla } & Parnassia glauca & & & & $4(2)$ & $<1$ & \\
\hline & Rhamnus alnifolia & & & & $4(3)$ & & $<1$ \\
\hline & Rhododendron groenlandicum & & $<1$ & $<1$ & $1(1)$ & $0(5)$ & \\
\hline San can & Sanguisorba canadensis & $5(2)$ & $2(1)$ & $<1$ & $3(1)$ & $<1$ & $7(2)$ \\
\hline \multirow[t]{2}{*}{ Sch tab } & Schoenoplectus tabernaemontani & & & & & & $5(2)$ \\
\hline & Symphyotrichum novi-belgii var. novi-belgii & $<1$ & $<1$ & $<1$ & $<1$ & $<1$ & $1(0.2)$ \\
\hline \multirow[t]{2}{*}{ Thu occ } & Thuja occidentalis & & $<1$ & & $26(17)$ & $47(13)$ & $1(0.5)$ \\
\hline & Triantha glutinosa & & & & $1(1)$ & & \\
\hline Tri alp & Trichophorum alpinum & $6(1)$ & $3(4)$ & $<1$ & & $1(1)$ & $19(6)$ \\
\hline \multirow[t]{2}{*}{ Tri ces } & Trichophorum cespitosum & & & & $25(10)$ & $1(2)$ & \\
\hline & Alnus spp. & $<1$ & $2(3)$ & $<1$ & & & $<1$ \\
\hline Cal can & Calamagrostis canadensis & $<1$ & $7(7)$ & $1(1)$ & & & $<1$ \\
\hline Dro rot & Drosera rotundifolia & $1(0.4)$ & $<1$ & $1(0.4)$ & & & \\
\hline \multirow[t]{2}{*}{ Equ arv } & Equisetum arvense & & $3(4)$ & $1(1)$ & & & \\
\hline & & & & & & 29 & \\
\hline
\end{tabular}




\begin{tabular}{|c|c|c|c|c|c|c|c|}
\hline & Eriophorum vaginatum & & $<1$ & $4(5)$ & & & \\
\hline Hyp vir & Hypericum virginicum & $1(0.3)$ & $<1$ & $<1$ & & & \\
\hline \multirow[t]{2}{*}{ Lyc uni } & Lycopus uniflorus & $<1$ & $2(2)$ & $<1$ & & & \\
\hline & Onoclea sensibilis & & $4(7)$ & & & & \\
\hline Sal spp & Salix spp. & & $2(1)$ & $<1$ & \multirow[t]{4}{*}{$<1$} & & $<1$ \\
\hline Sci cyp & Scirpus cyperinus & $<1$ & $19(11)$ & $<1$ & & & \\
\hline Spi lat & Spiraea alba var. latifolia & $1(2)$ & $4(2)$ & $3(2)$ & & & $<1$ \\
\hline \multirow[t]{3}{*}{ Typ lat } & Typha latifolia & & $2(1)$ & $<1$ & & & \\
\hline & True mosses $\|$ & $3(2)$ & $8(8)$ & $1(1)$ & $28(18)$ & $12(12)$ & $55(11)$ \\
\hline & Aulacomnium palustre & & $<1$ & & $<1$ & $<1$ & $1(1)$ \\
\hline \multirow[t]{5}{*}{ Cam ste } & Campylium stellatum & & $6(7)$ & & $21(19)$ & $2(4)$ & $17(8)$ \\
\hline & Climacium dendroides & & & & & & $5(5)$ \\
\hline & Pleurozium schreberi & & & & $<1$ & $4(9)$ & \\
\hline & Rhytidiadelphus triquetrus & & & & & $3(9)$ & \\
\hline & Scorpidium cossinii & & & & $4(9)$ & $1(2)$ & \\
\hline \multirow[t]{2}{*}{ Tom nit } & Tomenthypnum nitens & & & & $3(4)$ & $2(3)$ & \\
\hline & Unidentified mosses (spp.) & $3(2)$ & $2(2)$ & $<1$ & & $<1$ & \\
\hline \multirow[t]{3}{*}{ Sar exa } & Sarmentypnum exannulatum & & & & & & $24(10)$ \\
\hline & Polytrichum strictum & $<1$ & $1(2)$ & $1(1)$ & & & $<1$ \\
\hline & Sphagnum $\|$ & $3(3)$ & & & $22(20)$ & $25(17)$ & $15(7)$ \\
\hline Sph don* & Sphagnum fuscum & & & & & & $5(5)$ \\
\hline Sph rub & Sphagnum rubellum & $1(1)$ & & & $12(14)$ & $14(14)$ & \\
\hline Sph don* & Sphagnum teres & & & & & & $8(6)$ \\
\hline Sph war & Sphagnum warnstorfii & & & & $10(14)$ & $16(17)$ & $2(2)$ \\
\hline Sph don* & Sphagnum spp. & $2(2)$ & & & $3(8)$ & & $2(2)$ \\
\hline
\end{tabular}

Caption: A species was considered dominant if its mean abundance was at least $1 \%$ in one of the sectors. Empty cells mean that specie was absent from the sampling units while $<1$ mean that the species was present with a mean abundance lower than $1 \%$. Grayed lines are species that were not found in the natural fens (or were present with an abundance lower than $1 \%$ ). Plant surveys were performed in 2014 for the BSF restored and natural sectors, whereas they were performed in 2008 (before plant harvesting) for the donor site. 


\section{Figure captions}

Figure 1 The Bic-St-Fabien research area. Colours indicate the four restoration techniques. pH and electro-conductivity (EC; corrected following Sjörs 1952; $\mu \mathrm{S} \mathrm{cm}^{-1}$ ) values (mean (SD)) were measured on site between 2010 and 2015 with a portable metre (see Materials and Methods section), from samples collected between June and October. WMRF = Wooded Moderate-rich fen and OWNRF = Open Wooded Moderate-Rich Fen (see Materials and Methods section for more details). Source of orthophoto (2001) : Gouvernement du Québec.

Figure 2 Principal component analysis (scaling 1) performed on mean vegetation percent cover of three restored sectors of BSF and three sectors used as sources of propagules (two natural fens adjacent to the site and the donor site). Vegetation monitoring was performed for all BSF restored and natural sectors five years after the restoration (2014) while vegetation surveys in the donor site was performed one year before vegetation harvesting (2008). For BSF restored and natural sites, each point represent one $25 \mathrm{~m}^{2}$ sampling unit for which mean vascular plant cover was computed over 4 subsamples and over 8 or 12 subsamples for bryophytes, while for the donor site abundance of vascular species was evaluated in $1 \mathrm{~m}^{2}$ sampling units and bryophytes in $25 \mathrm{~cm} \times 25 \mathrm{~cm}$ quadrats. Square symbols represent restored sampling units while circle symbols represent the ones located in the natural fens and donor site. Arrows represent plant species where the 6-letter code stands for the first three letters of the genus followed by the first three letters of the species name (see Table 1 for complete species names). For the analysis, 53 species were included, but only those with a vector length exceeding the circle of equilibrium contribution (radius 0.19) are shown. Sphagnum fuscum and Sphagnum teres were grouped to Sphagnum spp as "donor Sphagnum group" (Sph don*) because if they had been considered individually, they were not frequent enough to be included in the analysis. 
Figure 3 Vegetation cover (\%) by strata two years after fertilizing treatments (four years after the restoration; $n=9$ ). Standard error is presented for total vegetation. Letters indicate significant differences between treatments (protected Fisher's LSD test; $p<0.05$ ) and apply for vascular plants, bryophytes and total covers. 


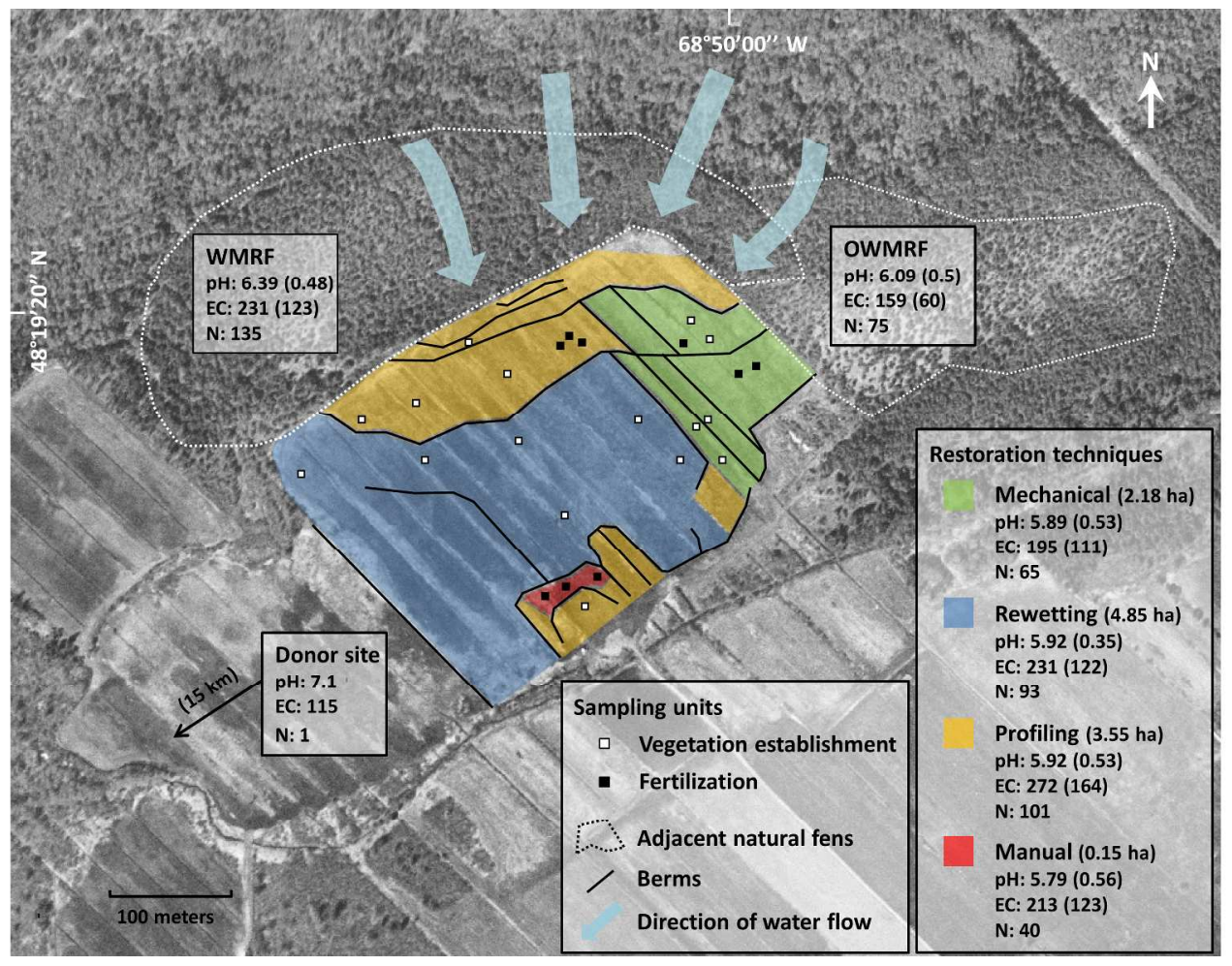

Figure 1 


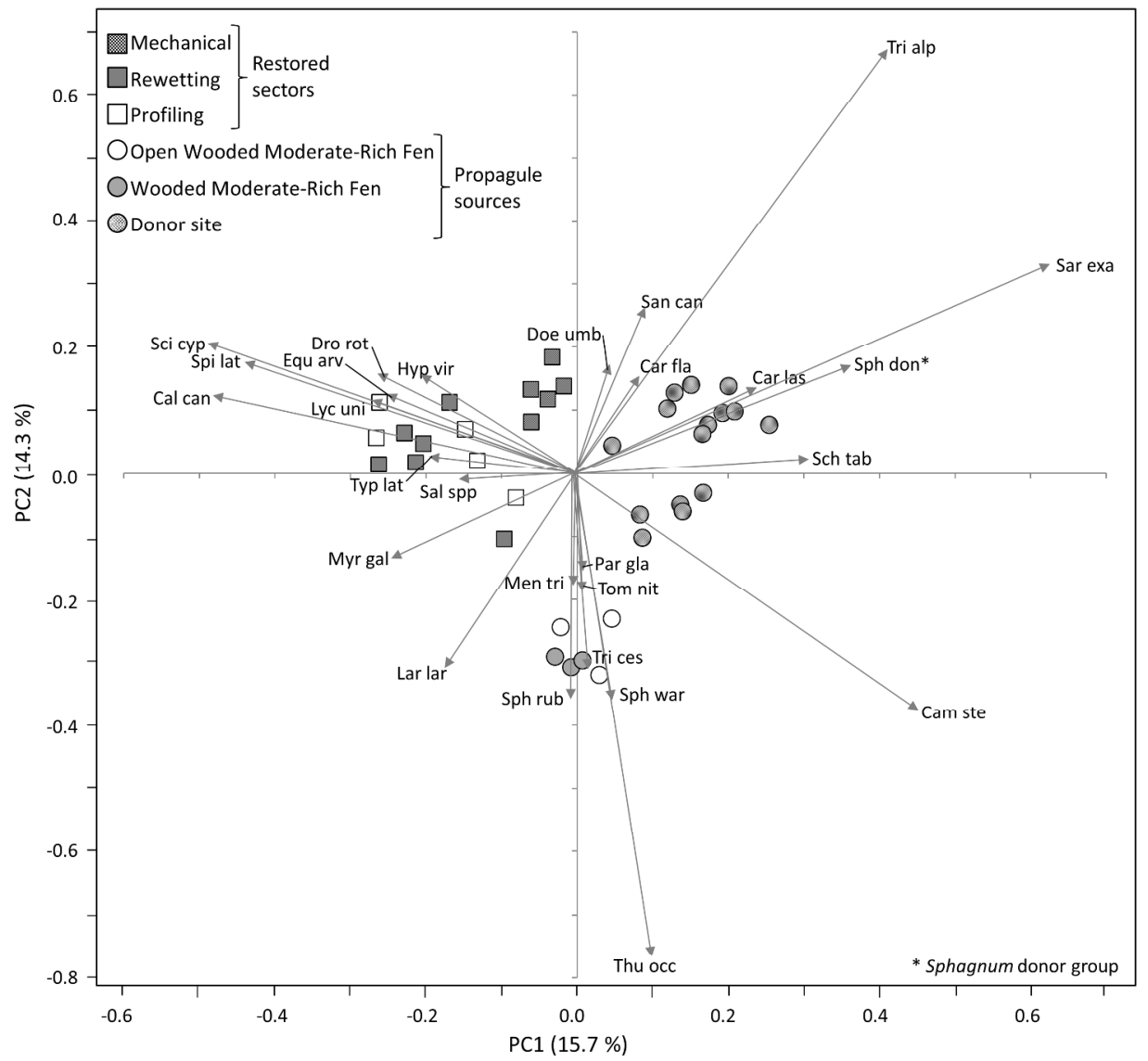

Figure 2 


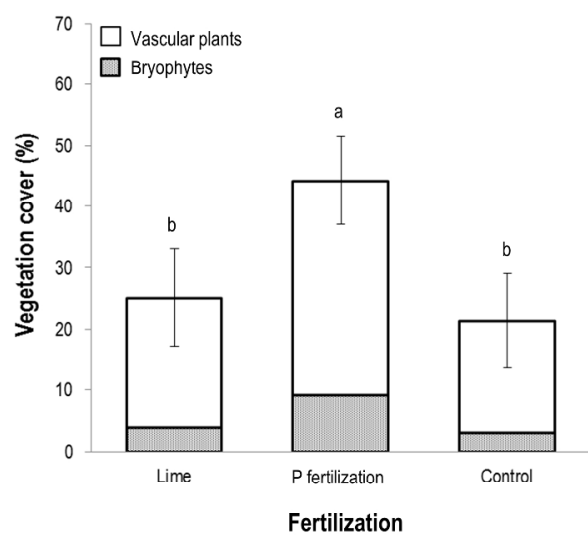

Figure 3 $254 \times 190 \mathrm{~mm}(300 \times 300 \mathrm{DPI})$ 